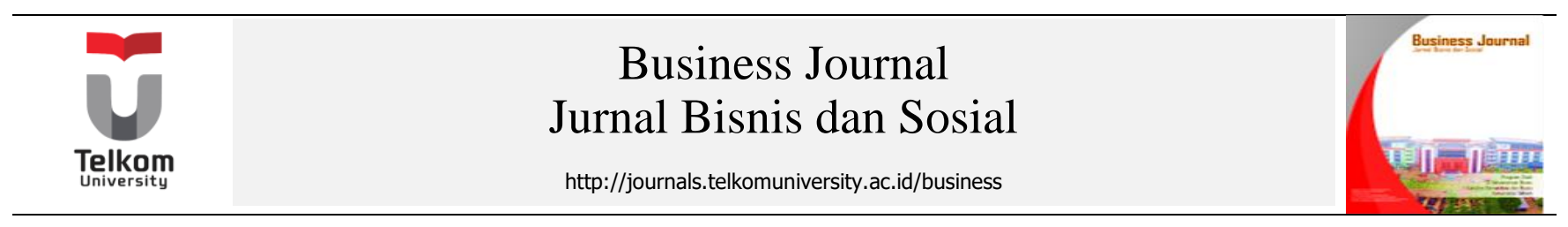

\title{
The Investigation Enhancement Effect Of Product Certification On Branding Toward Brand Trust
}

\author{
Fitriani Reyta ${ }^{1}$, Deden Novan Setiawan Nugraha $^{2}$, Dwinto Martri Aji Buana ${ }^{3}$ \\ ${ }^{1,2,3)}$ Business and Management Faculty of Universitas Widyatama, Bandung, Indonesia \\ ${ }^{1}$ fitriani.reyta@widyatama.ac.id, ${ }^{2}$ deden.novan@widyatama.ac.id, ${ }^{3}$ dwinto.mab@gmail.com
}

\section{N F O A R T I K E L}

Keyword:

Brand Trust, Disability, Product Certification, Branding, SMEs.

\begin{abstract}
A B S T R A K
Individuals with inabilities keep on expanding in Indonesia; the most astounding number of individuals with incapacities is in West Java Province, from the age gathering, ages 18-60 years possess. The most experienced inabilities were leg surrenders $(21.86 \%)$, mental hindrance $(15.41 \%)$ and discourse (13.08\%). Alluding to the consequences of an investigation from the University of Brawijaya Disability Study and Service Center, there were 1,835 individuals with handicaps in Bandung who required strengthening by government and non-legislative associations to build certainty of incapacities. Trust in the public arena assumes vital job in structure chances to incapacity SMEs, Bandung regional government itself underpins the handicap strengthening development, one of them is the making of DifablePunyaKarya (DPK) program in a joint effort with a non-legislative association called Mata Hati Indonesia. There are a few obstructions in running this program, from the consequences of perceptions in the field, the primary snag to DPK items is the network's trust in item quality, social disgrace, and not completely marked items (brand), no underwriters and not appropriate for utilization. This study examines how the branding can affect brand trust with product certification as moderating; the research approach used is quantitative with descriptive method and single cross-sectional research design. From the population of 200 consumers taken 67 samples using the Slovin formula, respondents taken were respondents who had bought DPK products and were domiciled in the city of Bandung, West Java. This study was tested using PLS (Partial Least Square Method) with the help of XLSTAT software.
\end{abstract}

\footnotetext{
Acknowledgment DRPM / 2019, March 8, 2019.

* Corresponding author at:

School of Communication \& Business, Telkom University,

Department of Business Administration

Jl. Telekomunikasi No. 1, Terusan Buah Batu, Bandung, 40257

Indonesia.

E-mail address: businessjournal@telkomuniversity.ac.id

ORCID ID:

- First Author: ID of the First Author
}

We would like to express deepest appreciation to all those who provided us the possibility to complete this research. A special gratitude presented to interviewees and respondent who have supported this research, our partner Mata Hati Indonesia and Difable Punya Karya Member and Founder also to the Directorate of Research and Community Service Directorate General for Strengthening Research and Development at the Ministry of Research, Technology and Higher Education Republic Of Indonesia for funding this research in accordance with research contract number: 110 / SP2H / PPM / 
- Second Author: ID of the Second Author

- Third Author: ID of the Third Author

- $\quad$ Fourth Author: 0000-0002-6976-7459

Published by School of Communication \& Business, Telkom University.

\section{Introduction}

In Indonesia, people with disabilities continue to increase, based on quotes from www.kemensos.go.id, the highest number of people with disabilities is in West Java Province (50.90\%). Of the age group, ages 18-60 years occupy the highest position. The most experienced disabilities were leg defects $(21.86 \%)$, mental retardation (15.41\%) and speech $(13.08 \%)$. Referring to the results of a study from the UB Disability Study and Service Center 2017, there were 1,835 people with disabilities in the city of Bandung who needed empowerment by both the government and non-governmental organizations. Empowerment is important to increase the self-confidence of persons with disabilities and a shift in social stigma towards disability, public trust plays an important role in building opportunities to work and work for disabilities. The same as a non-governmental organization called Mata Hati Indonesia.

In 2016 Mata Hati Indonesia gathered several disabilities who had strong motivation to work, through DPK they were given soft skills in various production processes, including food and craft products. In this program there are several obstacles, from the results of observations in the field, the main obstacle to DPK products is the community's trust in product quality, social stigma still not fully lost that the products with disabilities are not feasible consumed. This is consistent with previous research by Hamka (2010) that consumer trust in brands has a significant effect on purchasing decisions. According to Kotler and Armstrong (2012), brands have meaning as a name, term, sign, symbol, or design or a combination of them, which aims to identify goods or services produced by the manufacturer. According to him the brand will make it easier for consumers to identify products that are on the market, identify which products have more benefits, or which products are in accordance with consumer tastes. Moreover, the brand also states something about consistency and quality. This means that if the quality and consistency of a brand is good, it will be very easily accepted by consumers

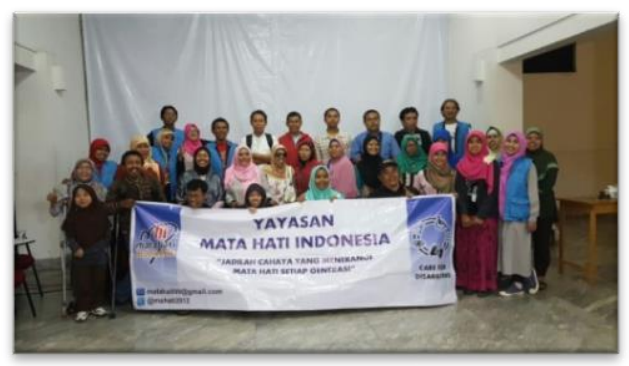

Figure 1. Mata Hati Indonesia Foundation "Monthly Gathering for Empowerment of Dissability" 


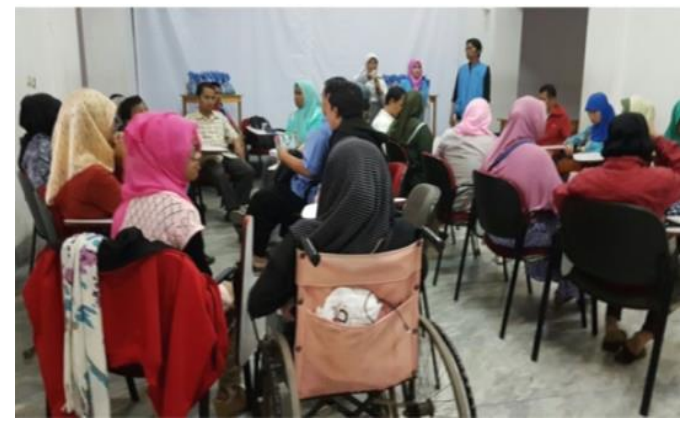

\section{Figure 2. Member of Difable Punya Karya (DPK) In Branding Workshop, as One Of Empowerment Programe From Mata Hati Indonesia}

The results of observations in the field also support the theory put forward by Delgado et al. (2005) that the philosophy of brand building is intended to build market trust in an offer, trust is a key factor that influences long-term relationships with consumers, especially when facing purchasing decisions have risky and expensive choices. In this case the products produced by DPK are products that are at risk, because they are produced by a disabled person, therefore a strong brand needs to be built, one of which is the inclusion of a certification logo. Based on the description above, the authors take the title "The Effect of Giving Brand Labels on Brand Trust Through Product Certification on Disability Products".

\section{Literature Review}

\subsection{Brand}

Brands are explained by Kotler and Gary Armstrong (2007: 70) brands are names, terms, signs, symbols, designs, or a combination of all of these that are intended to identify a product or service from someone or seller and to distinguish it from competing products. So the brand identifies the maker or seller of a product. A brand is also a seller's promise to deliver conclusions on the nature, benefits, and specific services consistently to the buyer. To measure the strength of a brand, brand equity is used. Aaker (1997: 23) reveals that brand equity creates value in both companies and consumers. This statement has been supported by several studies, including those conducted by Smith (2007: 107), which states that brand equity can be considered by companies in conducting mergers or acquisitions. Another study conducted by Lane (1995: 70), states that brand equity affects the response to the stock market. Brand equity can maintain the premium price of a product (Keller, 2003: 75), besides according to Rangaswamy in Yoo (2000: 200), brand equity can also influence the survival of a brand. Brand equity can be interpreted as the strength of a brand. Keller (2003: 56) 
mentions brand knowledge consisting of brand awareness and brand image as an indicator of brand equity.

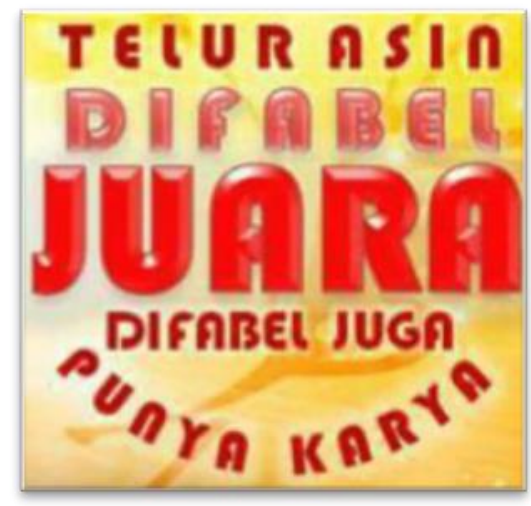

Figure 3. DPK Brand for Salted Egg Product called "Difabel Juara"

The use of Red in the brand is interpreted with passion, passion, energy, and action. Red is the primary color that usually dominates and refers to one of the psychological studies that red can stimulate appetite, according to the type of product that is salted egg. The use of the word champion refers to the large Indonesian dictionary, "JUARA" means 1) person (team) who wins the last match; 2) expert; smartest in something, this is what underlies or becomes the philosophy of DPK in naming "JUARA" as their brand for salted egg product. The word team refer to DPK goal as a team that strives to win a joint business competition and the word smartest refer to high quality product. The use of capital letters aims to create a strong and prominent impression on the minds of consumers

\subsection{Product Certification}

According to Kotler (2000: 347), "Product quality is a characteristic and characteristic of an item or service that affects its ability to satisfy expressed or implied needs". The quality of a product is the level of the level of good or bad which consists of all factors inherent in goods or services so that the goods have the ability to be used as desired by the consumers of these products.

Product certification according to Sucofindo (certification guarantee institution) is the provision of written guarantees from independent third parties that a product and the processes that support it have met health, secure, safety and environmental requirements. This certification aims to support the application of product safety standards, export facilitation through the agency of the export destination country, and industrial facilitation in the application of international standards. 
According to the National Certification Agency in the ISO / IEC 17067: 2013 Standardization Scheme, product certification is a conformity assessment activity that is built to provide the trust of consumers, regulators, industry and other interested parties that the product meets specified requirements, including for example performance, security, interoperability, and sustainable products in the territory of Indonesia, conformity to the Indonesian National Standards.

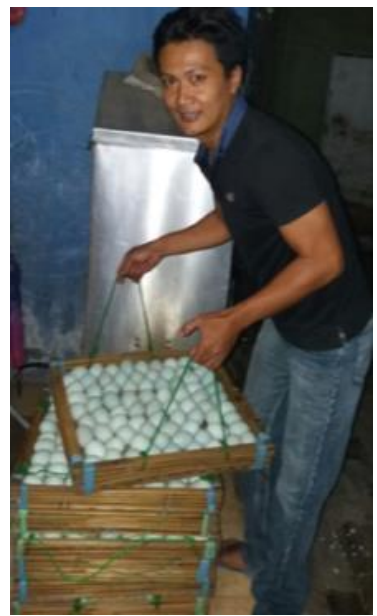

Figure 4. Production Process

Figure 4 describe the process production from raw material to ready to eat product with manual quality control that needs supervision from non-disability person for double checking that product meet the basic standard quality for salted egg such as cleanliness, healthy requirement, size and market taste standard.

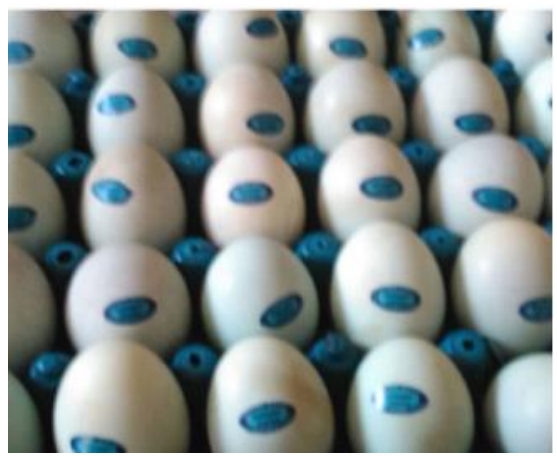

\section{Figure 5. Ready To Eat Product With Brand And Certification From P-IRT}

P-IRT is food production permit produced by the household industry scale set by BPOM (Drug and Food Control Agency) of Indonesia. Figure 5 are product development created after workshop collaboration from Bank Rakyat Indonesia (BRI) and salted egg business practician and duck farming lecturer, branding for this product use waterproof sticker and net 
for packaging, the reason DPK use sticker for each eggs is sticker are safer than using stamp directly to the eggs, the usage of brand with stamped tehnic are dangerous for product itself, the material from the stamp (ink) contain chemical ingredients who can absorp through the egg shell, than consumer will be food poisoned and raise another issue.

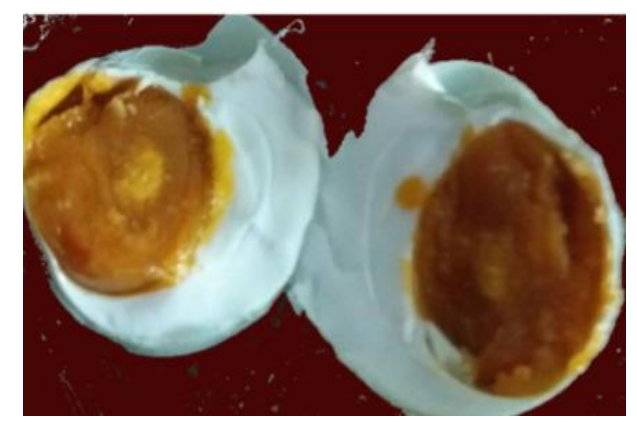

Figure 6. Product Quality

According to Ginting (2007) in guide to the results of poultry the indicator of salted egg from duck declare to be high quality when the color of the yolk is thick or concentrated towards the orange color, there are no blood or white spots on the yolk, the white egg is thick white, the surface of the shell is smooth, the contents of the egg are intact and there are no cracks. From figure 5 and 6 above can be seen that booth quality of inside and outside product are in good quality. For durability, the maximum best before date for consuming this salted egg is within 14 day, after that product will degrade in quality such as a pungent odor arises and freshness of the eggs plummets because of the microba growth because this product is an organic product that does not use chemicals for preservatives.

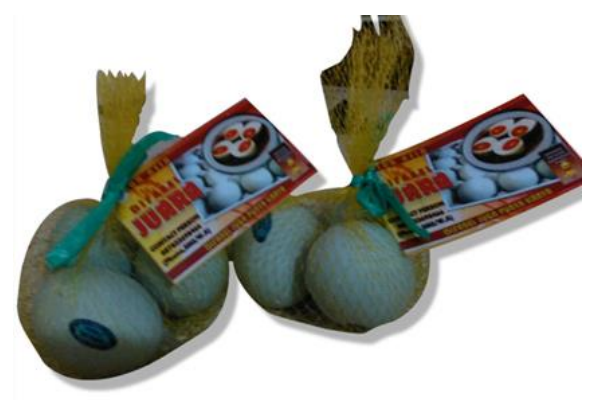

Figure 7. Product Packaging

Salted egg "JUARA"are packed with laminated bags of ethylene vinyl acetate / polyethylene (EVA/ PE) with the form of semi-disposable foam nets, labeled with product information such as expiration, nutritional content, product manufacturers and marketing contacts. 


\subsection{Brand Trust}

Delgado (in Ferinnadewi, 2008: 150)brand trust is the hope of brand reliability and good intentions. Based on this definition brand trust reflects two important components, the first is, consumer confidence that the product is able to meet the promised value or in other words the perception that the brand is able to meet consumer expectations by fulfilling the brand promise that ultimately creates customer satisfaction, the second, consumer confidence that the brand is able to prioritize the interests of consumers when problems in product consumption appear unexpectedly. According to Delgado (in Ferinnadewi, 2008: 150) brand trust is the hope of brand reliability and good intentions because that brand trust reflects two things namely brand reliability and brand intensions. (1) Brand reliability that comes from consumer confidence that the product is able to meet the promised value or in other words the perception that the brand is able to meet needs and provide satisfaction. (2) Brand intention is based on consumer confidence that the brand is able to prioritize the interests of consumers when problems in product consumption appear unexpectedly.

\subsection{Disability}

According to Law Number 19 Year 2011 concerning Ratification of the Rights of Persons with Disabilities, persons with disabilities, namely people who have physical, mental, intellectual or sensory limitations for a long period of time who interact with the environment and the attitudes of their people can encounter obstacles that make it difficult to participate fully and effective based on equality of rights.2 Law Number 4 of 1997 concerning Persons with Disabilities in the main points of convention point 1 (first) opening provides understanding, namely: Every person who has physical and / or mental disorders, which can interfere or constitute obstacles and relationships for him to do properly, consisting of, physically disabled people; disabled people mental; physically and mentally disabled. There are several types of people with special needs / disabilities. This means that each person with disabilities has their own definition which all need help to grow and develop properly. Types of persons with disabilities:

1. Mental Disability. This mental disorder consists of:

a) High Mental. Often known as intellectual gifted people, in addition to having intellectual abilities above the average he also has creativity and responsibility for the task. b) Low mentality. Low mental ability or intellectual capacity / IQ (Intelligence Quotient) below the average can be divided into 2 groups, namely slow learning children, namely children who have IQ (Intelligence Quotient) between 70-90. Whereas children 
who have IQ (Intelligence Quotient) below 70 are known as children with special needs. c) Specific Learning Difficulties. Learning difficulties related to achievement achieved

2. Physical Disability. This disorder includes several types, namely: Body Abnormalities (Forced Disease). Tunadaksa are individuals who have movement disorders caused by neuro-muscular abnormalities and structures that are congenital, sick or due to accidents (loss of the body), polio and paralysis. Based on the literature review, the research framework is arranged in the following figure:

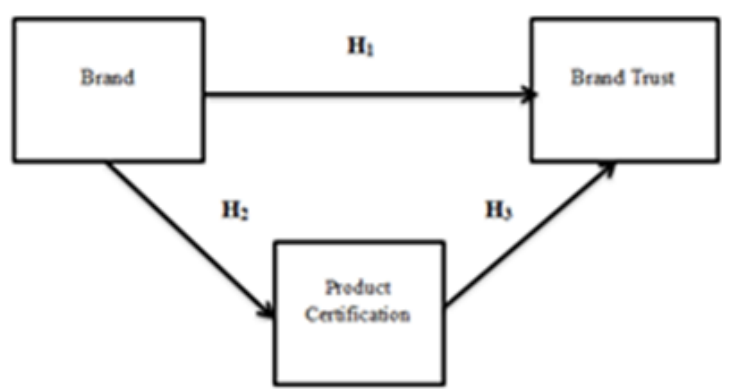

Figure 8. Research Framework

Based on the framework chart above, a hypothesis can be drawn as follows:

H1: There is an effect of using a brands on brand trust.

$\mathrm{H} 2$ : There is an effect of using a brand through product certification on brand trust.

H3: There is an effect of product certification on brand trust.

Thus the research paradigm can be arranged as follows:

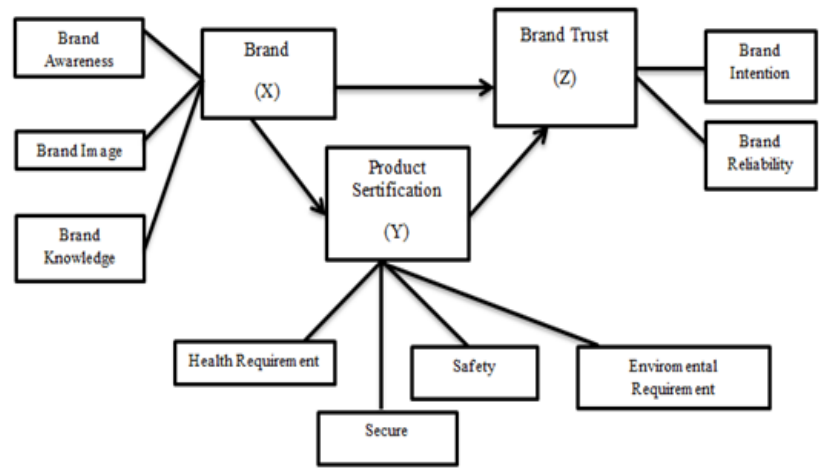

Figure 9. Research Paradigm

\section{Research Methodology}

The type of research conducted by researchers is descriptive research. This study belongs to a single cross-sectional design, namely research conducted once during one period (Malhotra, 2010: 108). Data collection is done by questionnaire survey techniques to respondents who are domiciled in the Bandung area and who have purchased products DPK. The data analysis technique in this study uses partial least square. Counter Least Square (PLS) is a regression 
family-based method introduced by Herman OA Wold for the creation and development of models and methods for social sciences with predictive oriented approaches. Data will be processed using the statistical method using XLSTAT software assistance.

The population for this study is all consumers of DPK products throughout Indonesia. According to Sugiyono (2013: 120) explains that: "Samples are part of the number of characteristics possessed by the population". In this study, the samples were consumers who had purchased DPK products and were domiciled in the city of Bandung. In determining the number of sample members the researchers determined that the average population of buyers for the past 1 (one) year was 200 consumers, and then the data was processed with Slovin formula as following:

Where:

$$
\begin{aligned}
\mathrm{n} & =\text { number of samples } \\
\mathrm{N} & =\text { number of population }=200 \\
\mathrm{~d} 2 & =\text { precision (set at } 10 \% \text { and } 90 \% \text { confidence level) } \\
\text { Based on the formula obtained the number of samples as follows: } & \\
\mathrm{n} & =\frac{200}{[200(0,1) 2+1]} \\
\mathrm{n} & =107,675 / 1077.75 \\
\mathrm{n} & =66.67 \\
& =67 \text { (rounded up) }
\end{aligned}
$$$$
\mathrm{d} 2=\text { precision (set at } 10 \% \text { and } 90 \% \text { confidence level) }
$$

In this study the sampling technique used is non-probability sampling with accidental sampling techniques. Data used to build this research are primary data and secondary data. Primary data is data that comes from researchers, collected by researchers to deal with a research problem faced obtained from the results of observations and questionnaires. While, secondary data is pre-existing data, which has been collected to solve research problems, secondary data in this study is the study of literature and consumer databases of DPK itself. 


\section{Results and Discussions}

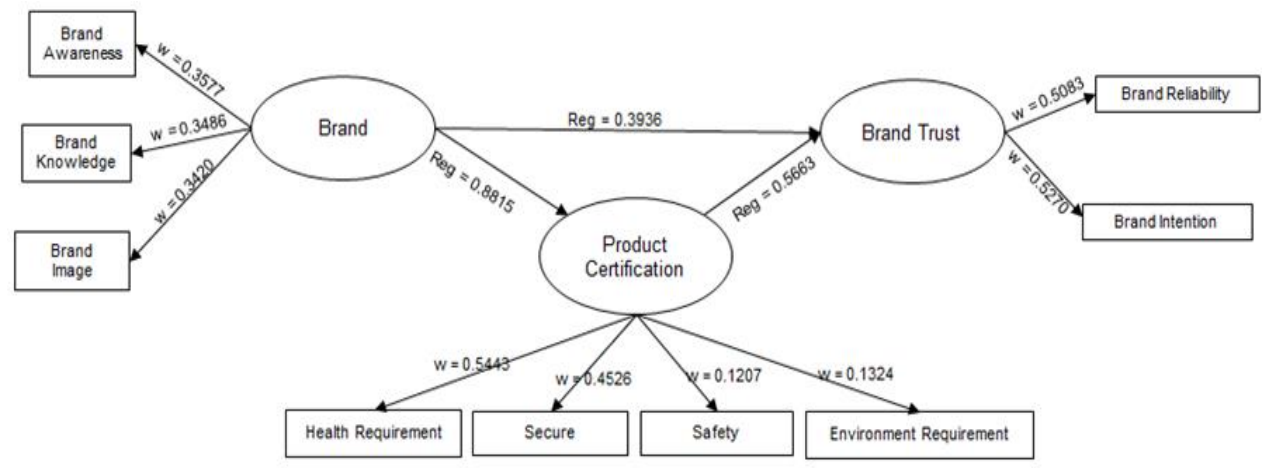

Figure 10. Hypothesis Result Run By XLSTAT

Table 1 Outer and Inner Model Evaluation

\begin{tabular}{|c|c|c|c|c|c|c|}
\hline \multicolumn{7}{|c|}{ Ovter Mea surement } \\
\hline \multirow[b]{2}{*}{ Variable } & \multirow[b]{2}{*}{ Dimension } & \multicolumn{2}{|c|}{ Validity } & \multicolumn{2}{|c|}{ Composite Reliability } & \multirow{2}{*}{$\begin{array}{c}\text { Inner } \\
\text { Measurement } \\
\text { Goodness Of } \\
\text { Fit Model }\end{array}$} \\
\hline & & $\begin{array}{c}\text { Cross } \\
\text { Loading }\end{array}$ & $\begin{array}{c}\text { Mean } \\
\text { Communalities } \\
\text { (AVE) }\end{array}$ & $\begin{array}{c}\text { Cronbachs } \\
\text { a pha }\end{array}$ & $\begin{array}{l}\text { D.G. rho } \\
\text { (PCA) }\end{array}$ & \\
\hline \multirow[t]{3}{*}{$\mathrm{Br}$ and } & $\begin{array}{l}\text { Brand } \\
\text { Awareness }\end{array}$ & 0.9482 & & & & \multirow{10}{*}{0.9587} \\
\hline & $\begin{array}{l}\text { Brand } \\
\text { Knowledge }\end{array}$ & 0.9699 & 0.9101 & 0.9506 & 0.9681 & \\
\hline & Brand Image & 0.9437 & & & & \\
\hline \multirow{5}{*}{$\begin{array}{c}\text { Product } \\
\text { Certification }\end{array}$} & Health & 0.9104 & & & & \\
\hline & Requirement & & & & & \\
\hline & Secure & 0.8709 & & & & \\
\hline & Safety & 0.4573 & 0.9329 & 0.9281 & 0.9653 & \\
\hline & Enviromental & 0.4159 & & & & \\
\hline \multirow[t]{2}{*}{ Br and Trust } & Brand Intention & 0.9646 & & & & \\
\hline & $\begin{array}{l}\text { Brand } \\
\text { Reliability }\end{array}$ & 0.9671 & 0.5923 & 0.7099 & 0.8214 & \\
\hline
\end{tabular}

Source : Processed Data Run By XLSTAT Software

From data above the results of data processsing from questionnaires using XLSTAT software indicate the indicator in convergent validity value of each variable has a factor loading more than 0.50 means the statement in the questionnaire valid, the higher the factor loading the higher the validity. From table 1 above show that the value AVE and communality from overall variable greater than 0.5 and met the criteria discriminant validity. So that it can be stated that the question items are valid in measuring the variable. For Reliability test using Cronbach Alpha and D.G. rho (PCA), from table 1 above the value of using Cronbach Alpha and D.G. rho (PCA) indicate that construct of each variable has a Cronbach Alpha more than 0.70 means the statement in the questionnaire reliable and can represent the variables in this study. The GoF value of 0.9587 means that the diversity of data can be explained by the model or in other words the information contained in the data is $95,87 \%$ can be explained by the model. While the remaining $4,13 \%$ is explained by other variables outside the model used in this study. 
Table 2 Hypothesis Result

\begin{tabular}{|c|c|c|c|c|c|c|c|c|}
\hline \multicolumn{9}{|c|}{ Effect } \\
\hline \multirow[b]{2}{*}{ Hypothesis } & \multicolumn{3}{|c|}{ Direct } & \multicolumn{4}{|c|}{ Indirect } & \multirow[b]{2}{*}{ Result } \\
\hline & $\begin{array}{c}\text { Path } \\
\text { Coefficient }\end{array}$ & $t$ test & Pr>t & $\begin{array}{c}\text { Variable } \\
\text { Exogenous }\end{array}$ & $\begin{array}{c}\text { Variable } \\
\text { Endogenous }\end{array}$ & $\begin{array}{c}\text { Intervening } \\
\text { variable }\end{array}$ & Effect & \\
\hline $\mathrm{H}_{1}$ & 0.3936 & 4.0698 & 0.0001 & & & & & Accepted \\
\hline $\mathrm{H}_{2}$ & & 14.936 & 0.0000 & Brand & Brand Trust & $\begin{array}{l}\text { Product } \\
\text { Certification }\end{array}$ & 0.2229 & Accepted \\
\hline H; & 0.5663 & 5.8563 & 0.0000 & & & & & Accepted \\
\hline
\end{tabular}

Source : Processed Data Run By XLSTAT Software

With the provision of:

1) $t$ arithmetic $>t$ table $=\mathrm{H}_{0}$ is do not accepted and $\mathrm{H}_{1}$ accepted.

2) $\mathrm{t}$ arithmetic $<\mathrm{t}$ table $=\mathrm{H}_{0}$ accepted and $\mathrm{H}_{1}$ is do not accepted.

The results of testing the direct effect hypothesis in this study can be seen in Table 2 the results from table show that: $(\mathrm{H} 1)$ effect using a brand on brand trust is significant, this can be seen from the t-count value of 4.0698 which is greater than t-table value of 1.67; (H3) product certificate has a significant effect on brand trust, this can be seen from the t-count value of 5.8563 which is greater than the value t-table which is equal to $1.67 ;(\mathrm{H} 2)$ product certification has a significant effect as moderating variable for brand and brand trust with the value as much as $0.2229(22.29 \%)$.

Previous research from Halim et all (2014) [15] support this result, it can be clearly said that there are significant influence on quality of product and brand image on customer trust, Sondoh Jr. et.al. (2007) , Ogba and Tan (2009) also support this result that brand that consist of brand image, brand knowledge and brand awareness positively influence brand trust. Supporting result state by Azizi (2014) [18] it conclude that after establishing a brand name that is outcome of ongoing high quality, brand appears to be a sign of quality. Quality is a subjective phenomenon. Consumer assessment of product quality determines its quality. Delgado (2005) said "trust a brand implicitly means that there is a high probability or expectancy that the brand will result in positive outcomes for the consumer". If a brand has a high quality, reliability will be guaranteed. in other words, brand quality is a sign of brand reliability. If consumer trusts the brand, it can be concluded that consumer believed that the brand has high quality.

\section{Conclusion and Recommendation}

In addition to market the products of disability entrepreneur, it requires a lot of stakeholder support, this is due to the limitations of the producers themselves. The most important thing consumers see about the products produced by a disability is that they can fulfill the quality according to standards, the results of observation and pretest illustrate consumer distrust of 
product quality, one of them is products from the DPK community, salted egg products that were not labeled and quality assurance certification makes sales drop significantly, from the results of these observations, it is formulated brand making and P-IRT registration as a guarantee of the quality of food products, after which the effect of brand trust on the same consumer is carried out, as many as 67 consumers of 200 consumers are taken as sample, product certification is designed as a mediator between brand and brand trust, the results obtained by the role of product certification is declared significant as a mediator because it meets the statistical test criteria, the presence of the brand has a higher influence on brand trust when being mediated by product certification.

In order to maximize the results of research in the long term, a greater range of population and samples is needed, strengthening quality certification also needs to be added to empower disabled children, knowledge about brands needs to be socialized with appropriate promotional media, research on the influence of promotional media also needs to be held.Government and private sector need to be involved in empowerment programs routinely to improve product quality of entrepreneurs who have mental and physical limitations, packaging design training, brand knowledge, communication and technology are their priority needs in addition to business operational funds. The results of this study are expected to encourage sustainable disability empowerment programs in Indonesia, especially the city of Bandung.

\section{Reference}

Kotler, Philip and Armstrong, Gary. 2012. Principles of Marketing. New Jersey: Prentice Hall.

Aaker, David. A (1997), Manajemen Ekuitas Merek. Memanfaatkan Nilai Dari Suatu Merek, Mitra Utama, Jakarta.

Armstrong, Garry \& Philip Kotler. Marketing an Introduction (Eight Edition). New Jersey: Pearson Prentice Hall. 2007.

Delgado, E., Munuera, J.L 2005. Does Brand Trust Matter To Brand Equity, Journal of Product and Brand Management, Vol. 14 No. 3, pp. 187-196.

Ferrinadewi, Erna. (2008). Merek \& Psikologi Konsumen. Yogyakarta: Graha Ilmu.

Ginting, Rosnani. 2007. Sistem Produksi Edisi Pertama, Yogyakarta : Graha Ilmu

Hamka. 2010, Pengaruh Trust In Brand Terhadap Brand Loyalty Pada Konsumen Air Minum AQUA Di Kota Ambon. Staff Pengajar FAPERTA UMMU,Ternate.

Halim, P., Swasto, B., Hamid, D., Firdaus, R. 2014. The Influence of Product Quality, Brand Image, and Quality of Service to Customer Trust and Implication on Customer Loyalty (Survey on Customer Brand Sharp Electronics Product at the South Kalimantan Province). European Journal of Business and Management. Vol.6, No.29, pp. 159-166.

Keller, K. L 2003, Strategic Brand Management: Building, Measuring, and Managing Brand Equity, 2nd Edition, Upper Saddle River (N.J.), Pearson Prentice Hall.

Kotler, Philip, 2000, Marketing Management. Edisi Milenium, Prentice Hall Intl, Inc New Jersey.

Lane, Vicki and Robert Jacobson. Stock Market Reactions to Brand Extension Announcements: The Effects of Brand Attitude and Familiarity. Journal of Marketing Vol. 59, No. 1 (Jan., 1995), pp. 63-77. Published by: American Marketing Association. 
Malholtra, N. (2010). Marketing Research: An Applied Orientation, 6th Edition. Upper Saddle River, NJ Pearson.

Ogba, Elechi dan Tan, ZhenZhen. (2009). Exploring the impact of brand image on customer loyalty and commitment in China. Newcastle Business School, Northumbria University, Newcastle upon Tyne, UK

Panahi, Monire dan Keivandaria Azhar, Azizi Ali. 2014. Investigating the Consumer Attitude Toward Green Marketing. European Journal of Business and Management Vol. 6, No. 11.

Smith, A. D. (2007). Making the case for the competitive advantage of corporate social responsibility.Business Strategy Series, 8(3), 186-195.

Sugiyono. (2013). Metode Penelitian Kuantitatif, Kualitatif dan R\&D. Bandung: Alfabeta.CV

Sondoh, S. L., Omar, M. W., \& et al. (2007). The Effect of Brand Image on Overall Satisfaction and Loyalty Intention in The Context of Color

Yoo, Boonghee, Naveen Donthu and Sungho Lee. An Examination of Selected Marketing Mix Elements and Brand Equity. Journal of the Academy of Marketing Science. 2000; 28; 195

www.kemensos.go.id 
Business Journal, Volume 5, N0 2, April 2019, p. 57-70, E-ISSN: 2620-3634, P-ISSN: 2407-6392 